\title{
A Retinal Pigment Epithelium-derived Cell Line from Transgenic Mouse Harboring Temperature-sensitive Simian Virus 40 Large T-antigen Gene
}

\author{
Keiichi Kato ${ }^{1 \dagger}$, Seiichi Ishiguro ${ }^{1}$, Hiroaki Yamamoto $^{2}$, Nobuaki Yanai $^{3}$, Masao Obinata ${ }^{3}$, and \\ Makoto Tamai ${ }^{1}$ \\ ${ }^{1}$ Department of Ophthalmology, Tohoku University School of Medicine, Tohoku University, Sendai, Miyagi \\ 980-77, Japan, ${ }^{2}$ Biological Institute, Graduate School of Science Tohoku University, Sendai, Japan and ${ }^{3}$ De- \\ partment of Cell Biology, Institute of Development, Aging and Cancer, Tohoku University, Sendai, Japan.
}

Key words: SV40 large T antigen/retinal pigment epithelium/laminin/growth factors/extracellular matrix

\begin{abstract}
$A B S T R A C T$. We established a retinal pigment epithelium-derived cell line from transgenic mouse harboring temperature-sensitive simian virus $40 \mathrm{~T}$-antigen gene (tsSV40T) and examined its characteristics. We enucleated both eyes from a 2-month-old transgenic mouse and removed the retinal pigment epithelial (RPE) cells and neuroretinal cells. After cloning the RPE cells, we obtained a cell line (RPET). RPET cells grew well at $33^{\circ} \mathrm{C}$ but not at $37^{\circ} \mathrm{C}$, expressing on the temperature-sensitive character of tsSV40T, and maintained characters of RPE cells such as T1-tyrosinase production, phagocytosis of rod outer segments, and presence of cytokeratin, microvilli on the cell surface and lysosome-like granules around the Golgi apparatus in the cytoplasm. Conditioned medium (CM) from a culture of neuroretinal cells harboring tsSV40T was essentially required for growth. The factor(s) in CM was heat- and acid labile, but was resistant to trypsin digestion. In the presence of $3 \% \mathrm{CM}$, epidermal growth factor (EGF) and basic fibroblast growth factor (bFGF) had strong growth effects on RPET cells, whereas insulin, insulin-like growth factor I (IGF-I), and IGF-II had moderate growth effects. Interestingly, none of these growth factors stimulated the RPET cells in the absence of CM. EHS-Matrix ${ }^{\circledR}$ had growth effect, whereas laminin, collagen types I and IV, and fibronectin had no marked growth effects on RPET cells. RPET cells were morphologically changed on a laminin-coated dish. They could not spread on the coated dish, and the majority of the cells floated. But when the floating cells were transferred to non-coated dishes, they immediately attached themselves. These results suggest that RPET cells are a good model for finding novel growth factor(s) and for investigating the mechanism of cell-laminin attachment.
\end{abstract}

Proliferative vitreoretinopathy (PVR) is a frequent cause of visual loss in retinal detachment. Because retinal pigment epithelial (RPE) cells are one of the im-

${ }^{\dagger}$ Reprint request: Keiichi Kato, Department of Ophthalmology, Tohoku University School of Medicine, 1-1 Seiryo-machi, Aobaku, Sendai, 980-77, Japan.

Abbreviations: bFGF, basic fibroblast growth factor; CM, conditioned medium from the culture of neural retina of transgenic mice; $\mathrm{CM}(+)$, conditioned medium using Eagle's minimum essential medium containing antibiotics and 5\% fetal bovine serum; $\mathrm{CM}(-)$, conditioned medium using Eagle's minimum essential medium containing antibiotics without $5 \%$ fetal bovine serum; DPBS $(-)$, calcium and magnesium-free Dulbecco's phosphate buffered saline; EGF, epidermal growth factor; FBS, fetal bovine serum; IGF-I; insulin-like growth factor I; IGF-II; insulin-like growth factor II; MEM, Eagle's minimum essential medium; PVR, proliferative vitreoretinopathy; ROS, rod outer segments; RPE, retinal pigment epithelium; RPET, After cloning retinal pigment epithelium derived-cells harboring temperature-sensitive simian virus $40 \mathrm{~T}$-antigen gene; tsSV40T, temperature-sensitive simian virus $40 \mathrm{~T}$-antigen gene; Tw-PBS, $0.05 \%$ Tween 20-phosphate buffered saline.

Tel: 81-22-717-7294, Fax: 81-22-717-7298 portant factors in PVR, investigation of mechanisms growth and cell adhesion of RPE can lead to the prevention and therapy of the disorder $(23,24,29)$. An established cell line of RPE may be useful for such studies. At present, immortal RPE cell lines from human and rat are available $(1,8,27)$. Previous studies have suggested that the immortalization of various cell types by SV40 large T-antigen could lead to stabilization of cell type-specific functions $(28,34,43,46,47)$, and the growth and differentiation of cell lines established by the ts mutant of SV40 T-antigen gene could be regulated by a temperature shift $(11,17,36,46,47)$. So we tried to establish a mouse RPE cell line using tsSV40T. The new cell line of mouse RPE, which we named RPET cells, have two interesting attributes. Firstly, they required conditioned medium from a culture of neuroretinal cells harboring tsSV40T (CM). Although RPE cells and neuroretinal cells are neighboring, the neuroretina-derived growth factor to RPE cells is unknown. Secondly, they were morphologically changed on a laminin-coated dish, which is not observed in nor- 
mal RPE cells. RPET cells are a good model for investigating RPE cell growth factor from neural retina and the mechanism of cell adhesion-detachment mechanism on PVR.

\section{MATERIALS AND METHODS}

RPE cell culture. We obtained RPE cells and neuroretinal cells from 2-month-old transgenic mice. After cloning the RPE cells, we obtained a cell line (RPET). All transgenic mice developed a choroid plexus tumor and died within 5 months. Eyes were enuculeated from 2-month-old F0 transgenic mice $(46,47)$, and we separated the anterior segment with lens and vitreous from the eye. Retinas were gently removed and treated for several seconds with $0.1 \%$ trypsin at room temperature. RPE cells were stripped from neural retina and were washed with Eagle's minimum essential medium (MEM) containing 5\% fetal bovine serum (FBS) and antibiotics (100 $\mathrm{U} / \mathrm{ml}$ penicillin $\mathrm{G}$ and $100 \mu \mathrm{g} / \mathrm{ml}$ streptomycin) by centrifugation at $1,000 \mathrm{rpm}$ for 5 minutes. The cells were maintained in MEM containing 5\% FBS and 50\% conditioned medium from the culture of neural retina of transgenic mice (CM). No growth of RPE cells was observed without CM. To certify the transformation, the DNA was isolated from the tail of each newborn mouse and the presence of intact $\mathrm{T}$-antigen gene was analyzed by Southern blotting (46).

Culture of tsSV4OT neural retinal cells and preparation of conditioned medium (CM). After removing the RPE cells, the remaining neural retinas were washed with calcium and magnesium-free Dulbecco's phosphate buffered saline (DPBS( -$)$ ) and were trypsinized. Trypsinized cells were washed with MEM containing 5\% FBS and antibiotics by centrifugation at 1,000 rpm for 5 minutes, then resuspended in the same media. The neuroretinal cells were cultured for 3 days, and the culture media were centrifuged for 10 minutes at $2,000 \mathrm{rpm}$, filtrated with $0.2 \mu \mathrm{m}$ pore filter, and used as CM. We collected two kinds of CM, one using MEM, antibiotics, and FBS $(\mathrm{CM}(+))$, and another using only MEM $(\mathrm{CM}(-))$. $\mathrm{CM}(+)$ was used for the experiments of growth rates, effects of growth factors, and the experiments of cell adhesion.

Culture of normal C57BL/6 mouse RPE cells. Eyes were enuculeated from 2-month-old C57BL/6 mice and rinsed three times in MEM containing $100 \mu \mathrm{g} / \mathrm{ml}$ kanamycin and 50 $\mu \mathrm{g} / \mathrm{ml}$ gentamycin. After a 90-min incubation with $40 \mathrm{U} / \mathrm{ml}$ testicular hyaluronidase and $80 \mathrm{U} / \mathrm{ml}$ collagenase, the eyes were incubated for 20 to $40 \mathrm{~min}$ in $0.1 \%$ trypsin $(1 \mathrm{ml} / \mathrm{eye})$ at $37^{\circ} \mathrm{C}$, and then transferred to MEM containing 5\% FBS and antibiotics. We removed the anterior segment and detached retina and RPE cells from choroid in DPBS( - ). RPE cells were gently separated from a sheet of neural retina in CTC solution (DPBS( - ) containing $6 \mathrm{U} / \mathrm{ml}$ collagenase, $0.1 \%$ trypsin, $4 \mathrm{mM}$ EDTA and $2 \%$ chick serum). After adding MEM containing 5\% FBS and antibiotics, RPE cells were centrifuged at 1,000 rpm for $3 \mathrm{~min}$. Two milliliters of MEM containing 20\% FBS and antibiotics per four eyes was added and plated on a $35-\mathrm{mm}$ dish.

Immuno Cytochemistry. RPET cells were plated on 8well glass chamber slides (Nunc); cultured for 3 days with MEM containing $5 \% \mathrm{FBS}, 20 \% \mathrm{CM}(+)$, and antibiotics; and fixed with absolute ethanol. These cells were treated with $0.3 \%$ of hydrogen peroxide in methanol and then blocked with 5\% FBS-MEM. They were rinsed in $0.05 \%$ Tween 20 PBS (Tw-PBS), and incubated for 24 hours with a $1: 100$ diluted rabbit antibody against mouse $\mathrm{T} 1$-tyrosinase ${ }^{15}$ in PBS at $4^{\circ} \mathrm{C}$. After washing with Tw-PBS, samples were treated with peroxidase-labeled goat anti-rabbit IgG (1:200) (TAGO) for 12 hours at $4^{\circ} \mathrm{C}$. Staining was carried out with DAB solution. Controls were treated with normal rabbit serum instead of the first antibody.

Morphological studies. In a subconfluent state, RPET cells were fixed with $2.5 \%$ glutaraldehyde and $1 \%$ osmic acid, dehydrated by ethanol, and embedded in Epon. For phagocytosis studies, bovine rod outer segments (ROS, final $2 \mathrm{mg}$ $/ \mathrm{ml}$ ) in MEM containing antibiotics were added to the subconfluent RPET cells and incubated for 6 hours at $33^{\circ} \mathrm{C}$. Phagocytosis of the ROS was observed by electron microscopy.

Western blotting. RPET cells were trypsinized and suspended in PBS. After sonication, samples ( $5 \mu \mathrm{g} / \mathrm{lane})$ were applied on SDS-PAGE and transferred to nitrocellulose membrane. After washing with PBS and blocking with 5\% skim milk and 3\% gelatin at room temperature for 60 minutes, the membrane was treated with prediluted anti-human pan cytokeratin antibody $(1: 200)$ (Sigma) at $37^{\circ} \mathrm{C}$ for 60 minutes. The membrane was washed with Tw-PBS and incubated for 60 minutes with alkaline phosphatase-labeled goat anti-mouse IgG (1:5000) (TAGO) at $37^{\circ} \mathrm{C}$. Staining was carried out with $5 \mathrm{ml}$ of staining buffer $(100 \mathrm{mM}$ Tris-HCl buffer, $\mathrm{pH} 9.5,100$ $\mathrm{mM} \mathrm{NaCl}, 5 \mathrm{mM} \mathrm{MgCl}$ ) containing $33 \mu \mathrm{l}$ of NBT $(50 \mathrm{mg} / \mathrm{ml}$ nitroblue tetrazolium in $70 \%$ dimethylformamide) and 16.5 $\mu \mathrm{l}$ of BCIP $(50 \mathrm{mg} / \mathrm{ml} 5$-bromo-4-chloro-3-indolyl-phosphate, toluidine salt in dimethylformamide). Controls were treated without the first antibody.

\section{Growth characteristics.}

Properties of the factor(s) in CM. $\mathrm{CM}(-)$ was used to examine the dose-dependency of the RPET cells. To investigate the nature of $\mathrm{CM}, \mathrm{CM}(-)$ was treated (a) 5 minutes at $80^{\circ} \mathrm{C}$, (b) 30 minutes at $\mathrm{pH} 2$ at room temperature, and (c) $60 \mathrm{~min}$ utes with $100 \mu \mathrm{g} / \mathrm{ml}$ trypsin at $37^{\circ} \mathrm{C}$. To estimate the approximate molecular weight of the factor, CMs were divided by ultrafiltration through $10 \mathrm{kD}$ cut-off membrane (Millipore). Activation of the filtrate and remaining samples were determined. After plating at a concentration of $1 \times 10^{4}$ cells $/$ dish (12-well plates) with MEM containing 5\% FBS, antibiotics, and $20 \% \mathrm{CM}$, the cells were incubated for 1 day at $33^{\circ} \mathrm{C}$. Using the medium containing $10 \%$ each treated $\mathrm{CM}(-)$ and $5 \%$ FBS, cultures were continued for 6 days. The whole cell number was counted by a Coulter Counter ${ }^{\circledR}$. Medium exchanges were performed every 3 days.

Effects of known growth factors. To examine the effects of known growth factors on RPET cells, basic fibroblast 
growth factor (bFGF, $10 \mathrm{ng} / \mathrm{ml}$, stable mutant TGP-580, Takeda Chemical Ind.) (37), epidermal growth factor (EGF, $10 \mathrm{ng} / \mathrm{ml}$, Upstate Biotechnology, Inc.), insulin $(500 \mathrm{ng} / \mathrm{ml}$, Boehringer-Mannheim), insulin-like growth factor I (IGF-I, $10 \mathrm{ng} / \mathrm{ml}$, Seikagaku Corporation, Japan), and IGF-II (10 ng $/ \mathrm{ml}$, Seikagaku Corporation, Japan) were used. After plating at a concentration of $1 \times 10^{4}$ cells/dish (12-well plates) with MEM containing 5\% FBS, antibiotics, and 20\% CM, the cells were incubated 1 day at $33^{\circ} \mathrm{C}$. In the presence of $\mathrm{CM}$ and growth factors, cultures were continued for 6 days. Effects of growth factors were determined also in the absence of CM. In that case, cultures were continued for 14 days. The whole cell number was counted by a Coulter Counter ${ }^{\circledR}$. Medium exchanges were performed every 3 days.

Effects of extracellular matrices. To examine the growth effects of collagen type I $\left(5 \mu \mathrm{g} / \mathrm{cm}^{2}\right)$, collagen type IV $(19 \mu \mathrm{g}$ $\left./ \mathrm{cm}^{2}\right)$, fibronectin $\left(2 \mu \mathrm{g} / \mathrm{cm}^{2}\right)$, laminin $\left(9 \mu \mathrm{g} / \mathrm{cm}^{2}\right)$, and EHSNatrix $^{\circledR}$ (Becton-Dickinson laboware), RPET cells $\left(2 \times 10^{4}\right.$ cells/dish) were incubated for 14 days at $33^{\circ} \mathrm{C}$ with MEM containing 5\% FBS, antibiotics, and 20\% CM(+) onto ECMcoated dishes (6-well plates, Becton-Dickinson laboware). After 14 days' incubation, the whole cell number was counted by a Coulter Counter ${ }^{\circledR}$. Medium exchanges were performed every 3 days.

To examine the cell adhesion to laminin, RPET cells were plated at a concentration of $2 \times 10^{4}$ cells/dish onto a noncoated dish or a laminin-coated dish. After 24 hour, the number of the floating cells and attached cells were counted by a Coulter Counter ${ }^{\circledR}$.

As a control, C57BL/6 mouse RPE cells, secondary cultured cells were used. After 2 weeks, the cultured normal RPE cells were collected by CTC solution and cultured on the laminin-coated dish.

\section{RESULTS}

Biological characteristics of RPET cells. We examined whether RPET cells retained the characteristics of normal RPE cells. In immunohistochemistry, RPET cells produced T1-tyrosinase in the cytoplasm (Fig. 1). RPET cells had many microvilli that are typical of normal RPE cells (41) (Fig. 2a). Many lysozome-like granules around the Golgi apparatus were observed in the cytoplasm (Fig. 2b), but there were no melanosomes. Phagocytosis of the tips of the renewing photoreceptor outer segments (ROS) is one of the important functions of RPE cells in vivo $(21,48,49)$ and can be demonstrated in primary cultures of RPE cells fed with isolated $\operatorname{ROS}(2,4,9,10,27,35)$. RPET cells had the phagocytotic function of bovine ROS (Fig. 2c), and engulfed the ROS in the cytoplasm of RPET cells. Presence of cytokeratin is one of the markers for epithelial cells in vivo and in vitro, and RPE cells also produces cytokeratins in culture $(12,14,25,26,32,40-42)$. Immunohistochemical staining revealed the presence of cytokeratin
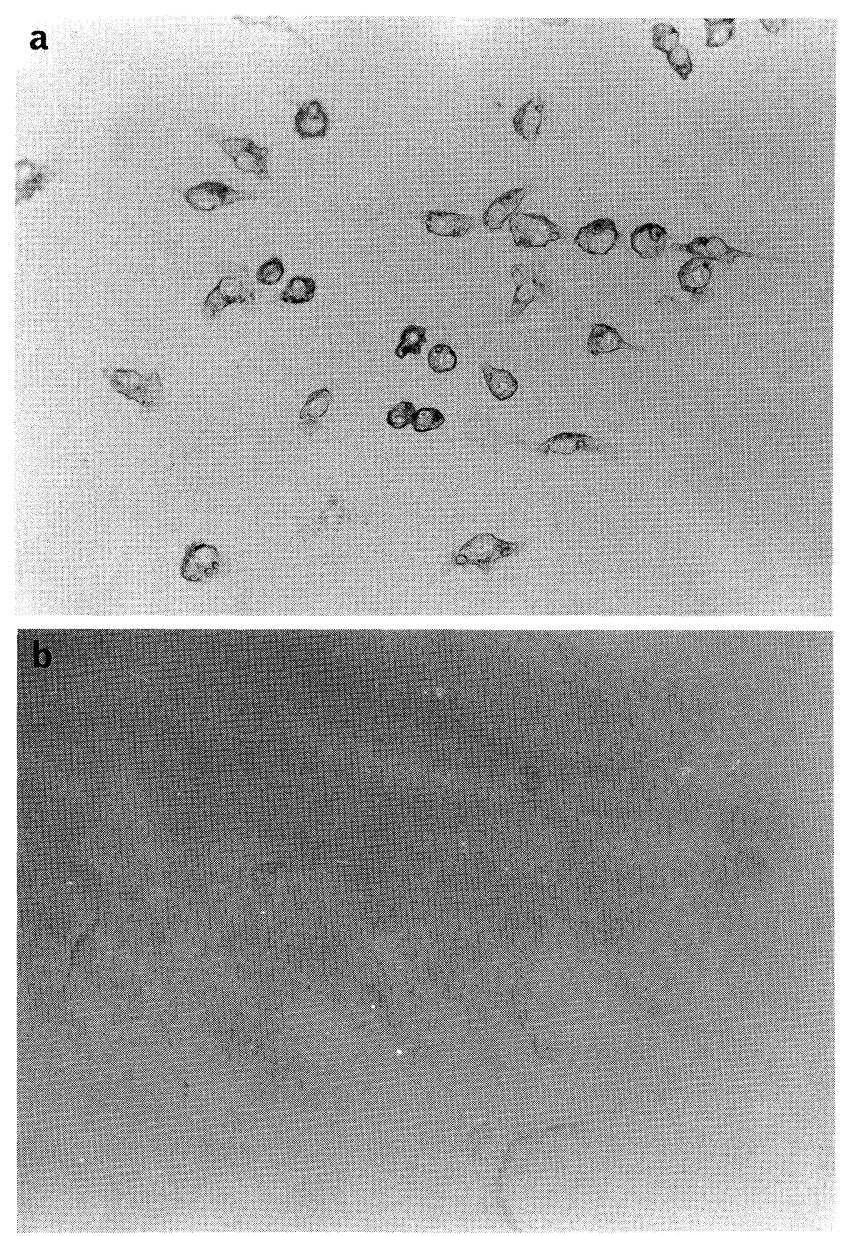

Fig. 1. Immunocytochemistry of RPET cells by anti-mouse T1-tyrosinase antibody. (A) RPET cells showed strong staining in the cytoplasm. (B) control.

in this cell line (Fig. 3). One major and 1 minor band observed at molecular masses of about $51 \mathrm{kD}$ and $59 \mathrm{kD}$ were apparent. This monoclonal antibody to cytokeratin recognized cytokeratin $1,4,5,6,8,10,13,18$, and 19.

Growth effects of CM. RPET cells exhibited temperature sensitive growth in the presence of $\mathrm{CM}$. The cells grew at $33^{\circ} \mathrm{C}$, but not at $37^{\circ} \mathrm{C}$ (Fig. 4 a). Even at $33^{\circ} \mathrm{C}$, $\mathrm{CM}$ was essentially required for growth. Ten percent CM was enough to support the RPET cell growth (Fig. 4b). Population doubling time was about 94 hours under such conditions. Without CM, RPET cells could not grow under the condition of using 20\% FBS (data not shown).

We investigated the properties of the factor(s) in CM. The factor(s) is heat- and acid labile. CM treated at $80^{\circ} \mathrm{C}$ for 5 minutes and treated at $\mathrm{pH} 2$ at room temperature for 30 minutes could not stimulate RPET cell growth, but trypsin-digested CM stimulated cell growth 

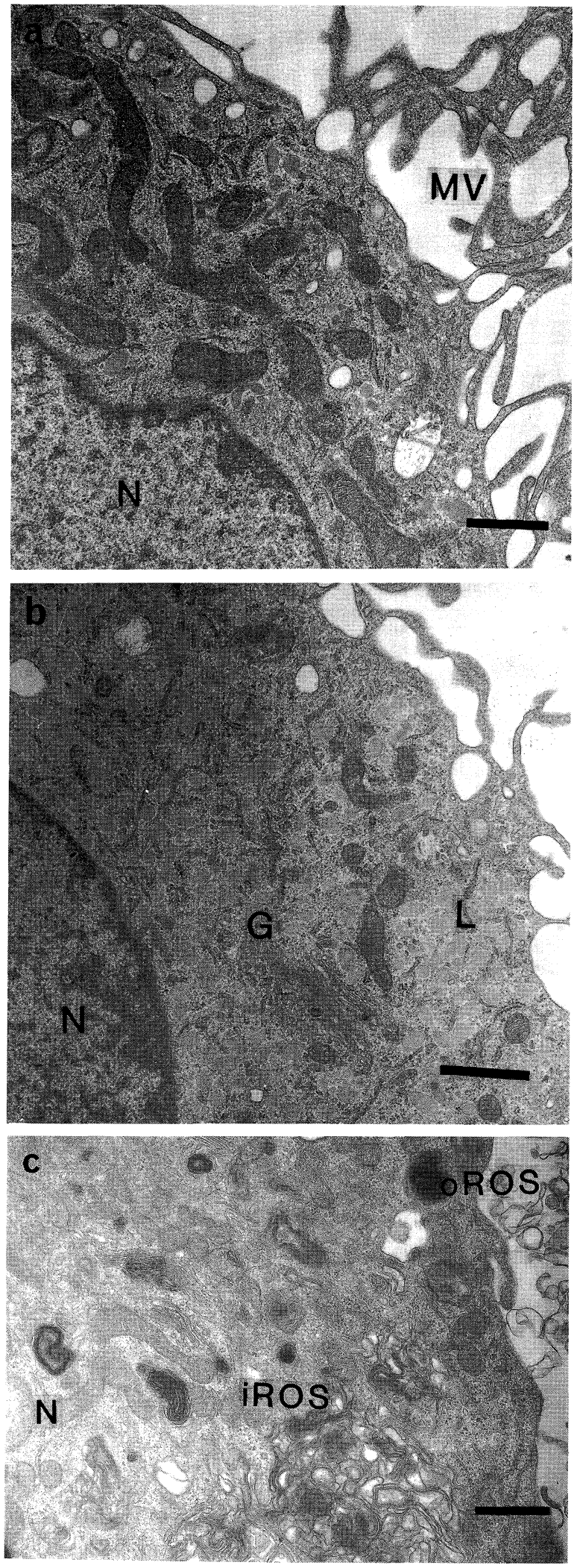

Fig. 2.

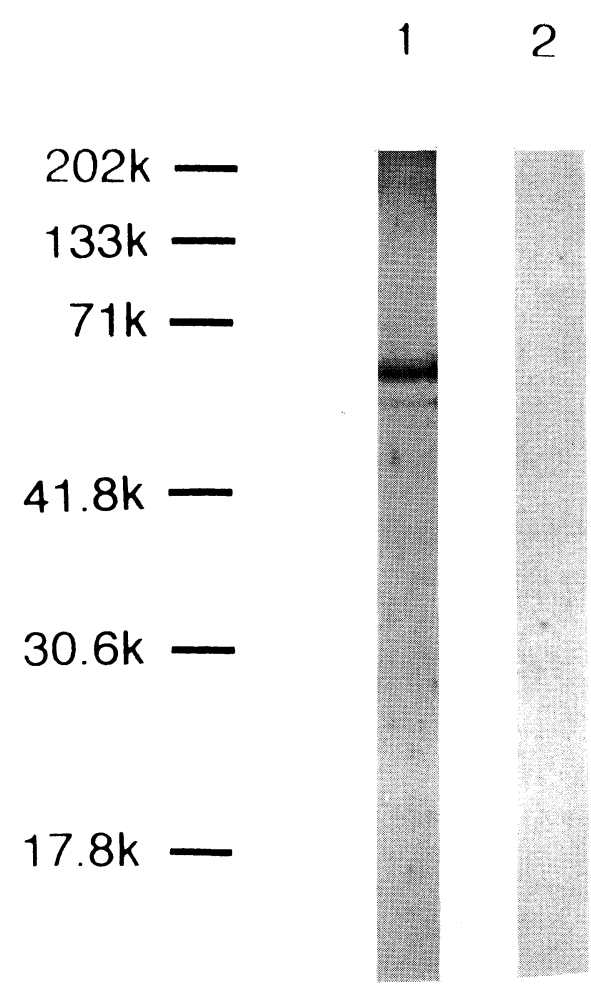

Fig. 3. Western blotting of cytokertatin in RPET cells. Lane 1: anti pan cytokeratin; Lane 2: control.

(Fig. 5). This growth effect of CM was not observed at the $<10 \mathrm{kD}$ fraction, but it was seen at the $>10 \mathrm{kD}$ fraction. The $>10 \mathrm{kD}$ fraction and the combination of two fractions had the same effect as native $\mathrm{CM}$ on RPET cells (Fig. 6). The effects of CM were dose-dependent (data not shown).

Effects of growth factors. Figure 7 shows the growth effects of well-known growth factors on RPET cells. EGF and bFGF had marked growth effects. Insulin and IGF-I and IGF-II had moderate growth effects (Fig. 7a). Interestingly, in the absence of $\mathrm{CM}$, no growth factor could stimulate RPET cell growth, even if the factors were used in combination (Fig. 7b).

Effects of ECM. Growth effects of ECM on RPET cells are shown in Figure 8. EHS-Natrix ${ }^{\circledR}$ produced growth effects (63\% increase). The growth effect of fibronectin rate was low (16\% increase). Collagen types I and IV had no growth effect, while laminin had a slight inhibitory effect (17\% decrease).

RPET cells showed dramatic morphological changes

Fig. 2. Electron microscopy of RPET cells. (a) Many microvilli (MV) were seen on the cell surface. Nucleus (N). (b) Lysozome-like structures (L) were observed around the Golgi apparatus (G). (c) Phagocytosis of isolated bovine rod outer segments (ROS). Many ROS were seen in the cytoplasm (iROS). Non-phagocytotic ROS were seen outside the RPET cells (oROS). Bars indicate $1 \mu \mathrm{m}$. 


\section{a}

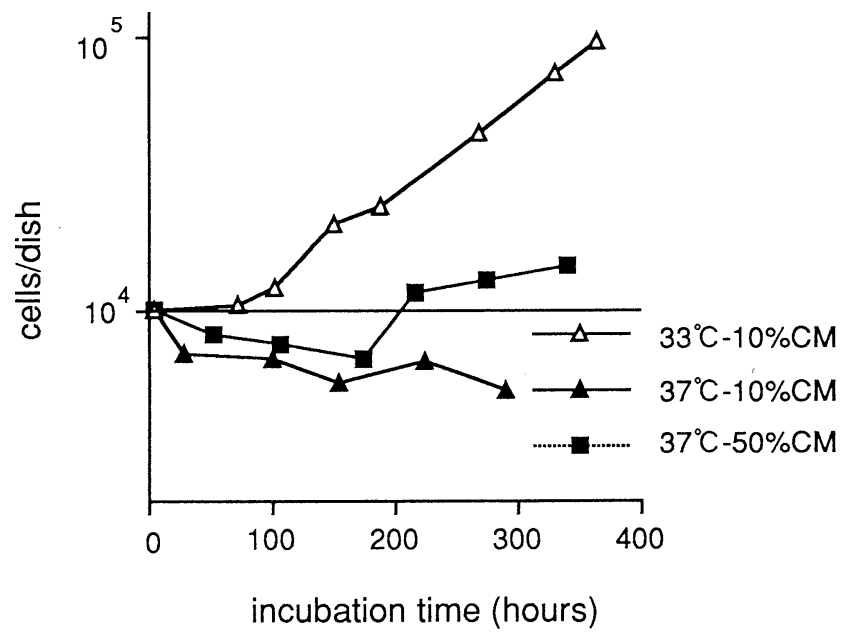

b

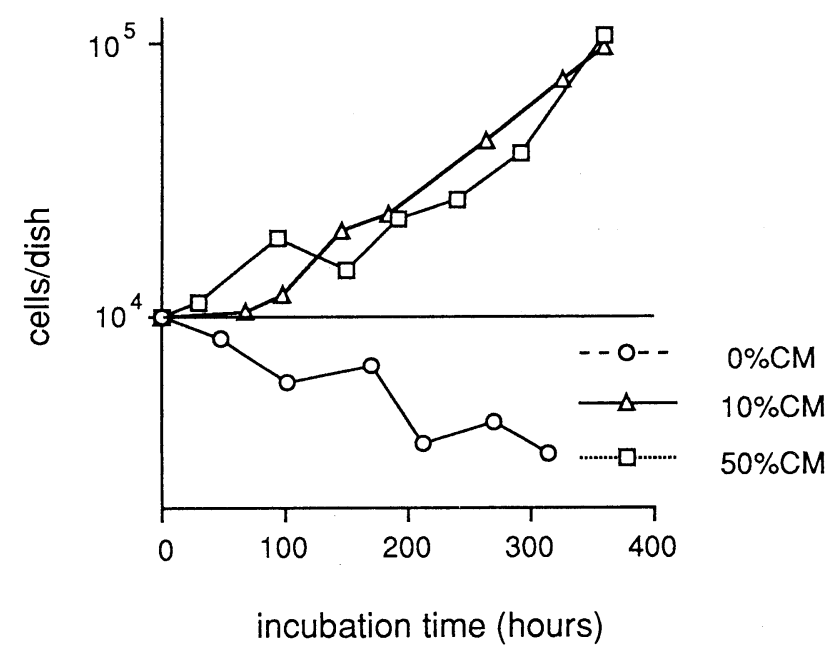

Fig. 4. Growth curve of RPET cells. (a) Temperature sensitivity. Open triangles show $33^{\circ} \mathrm{C}, 10 \% \mathrm{CM}$; closed triangles show $37^{\circ} \mathrm{C}$, $10 \% \mathrm{CM}$; closed squares show $37^{\circ} \mathrm{C}, 50 \% \mathrm{CM}$ in medium. RPET cells grew at permissive temperatures, but not at non-permissive temperatures. (b) Requirement of CM from cultured tsSV40 neuroretina for cell growth at permissive temperatures. Open circles show no CM; open triangles show 10\% CM; open squares show 50\% CM in medium. Even at permissive temperatures cells need $\mathrm{CM}$ for growth.

on the laminin-coated dish. On the non-coated dish, RPET cells spread and attached the dish (Fig. 9a). But the cells were round and detached from substratum (Fig. 9b). The majority of the cells could not attach to the laminin-coated dish (Fig. 10). Floating RPET cells proliferated and formed clumps of colonies (Fig. 9c).

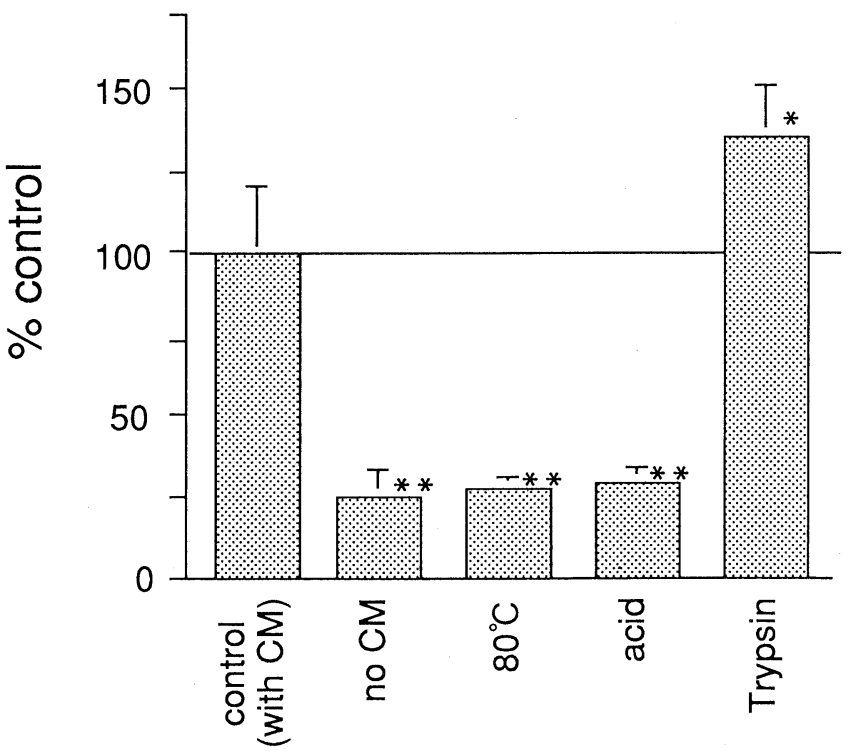

Fig. 5. Properties of the unknown factor(s) in CM. The factor(s) are heat- and acid labile, but are resistant for trypsin digestion. Control is used no-treated CM. Bars indicate mean \pm SEM.

${ }^{*}: \mathrm{p}<0.05{ }^{* *}: \mathrm{p}<0.005$.

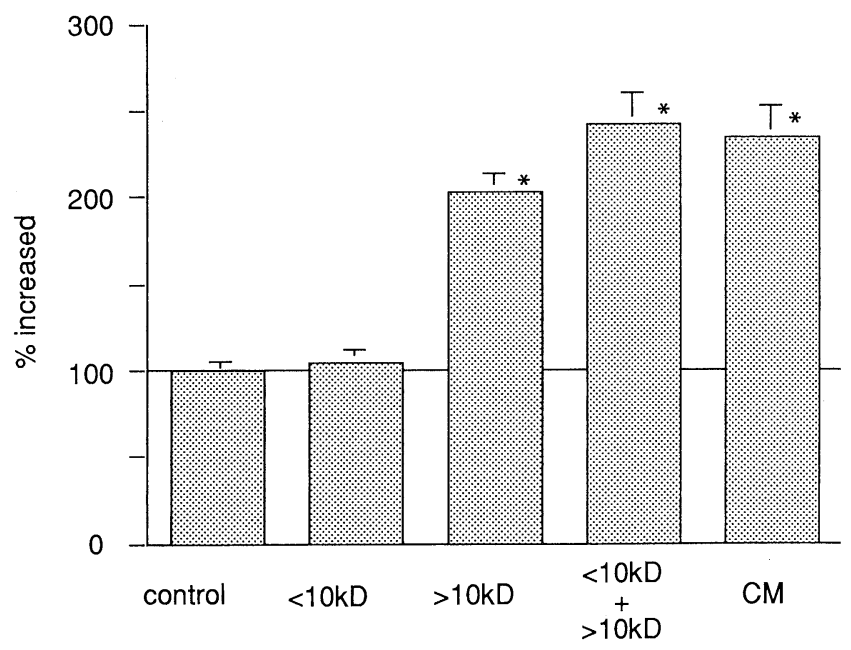

Fig. 6. Approximate molecular weight of the factor(s) in CM. This growth effect of CM was not observed at $<10 \mathrm{kD}$ fraction but was observed at $>10 \mathrm{kD}$ fraction. Bars indicate mean \pm SEM. ${ }^{*}: \mathrm{p}<0.005$.

When floating RPET cells were transferred to a noncoated dish, the cells immediately attached to the dish (Fig. 9d). Other ECM and well-known growth factors had no remarkable morphological changes on the RPET cells. The same morphological changes were not observed in tsSV40T neuroretinal cells (Fig. 9e) or in normal C57BL/6 mouse RPE cells (Fig. 9f). 


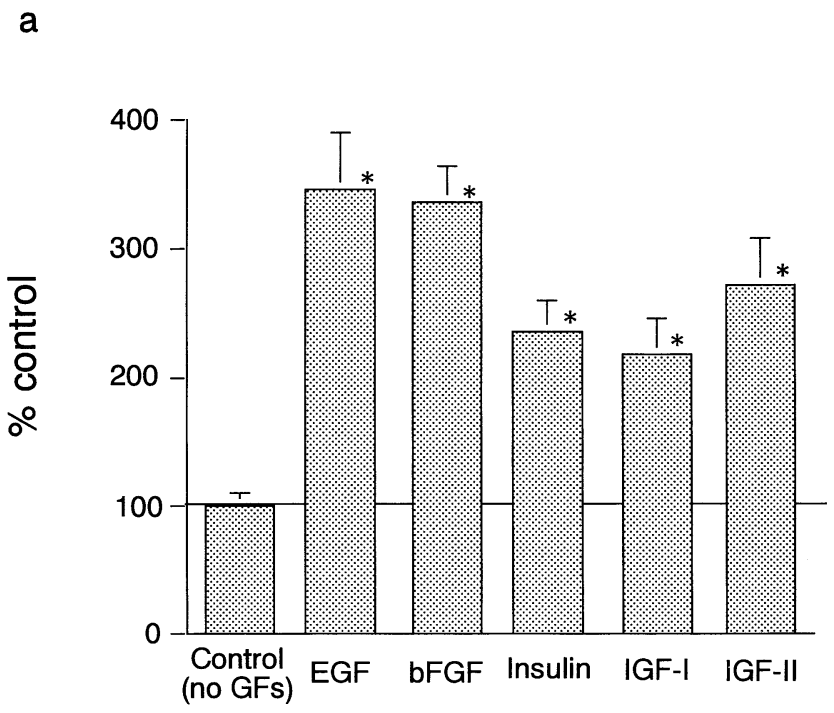

b

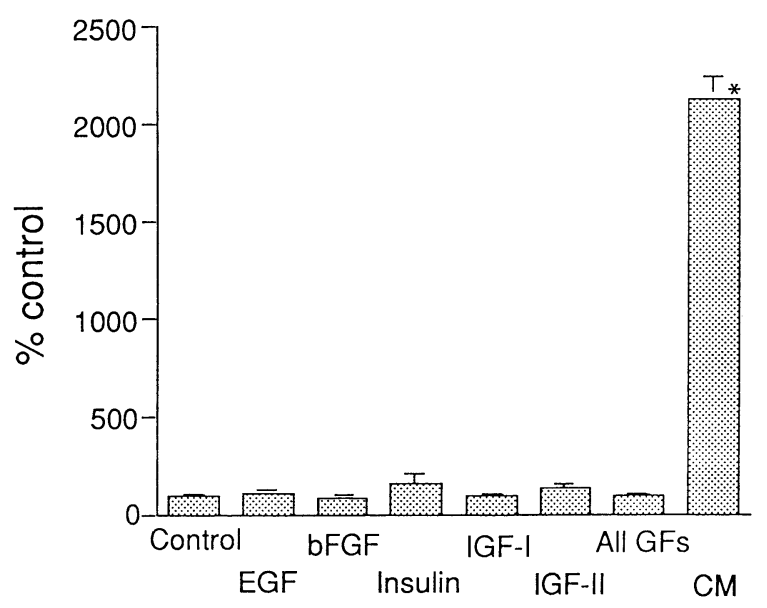

Fig. 7. The growth effects of growth factors to RPET cells. (a) Every growth factor stimulated RPET cell growth in the presence of CM. GFs: growth factors. (b) In the absence of CM, no growth factor, even when all five were combined, could stimulate cell growth. Bars indicate mean \pm SEM. *: $\mathrm{p}<0.005$.

\section{DISCUSSION}

We established an RPE cell line harboring tsSV40T. This cell line (RPET cells) had unique characteristics,

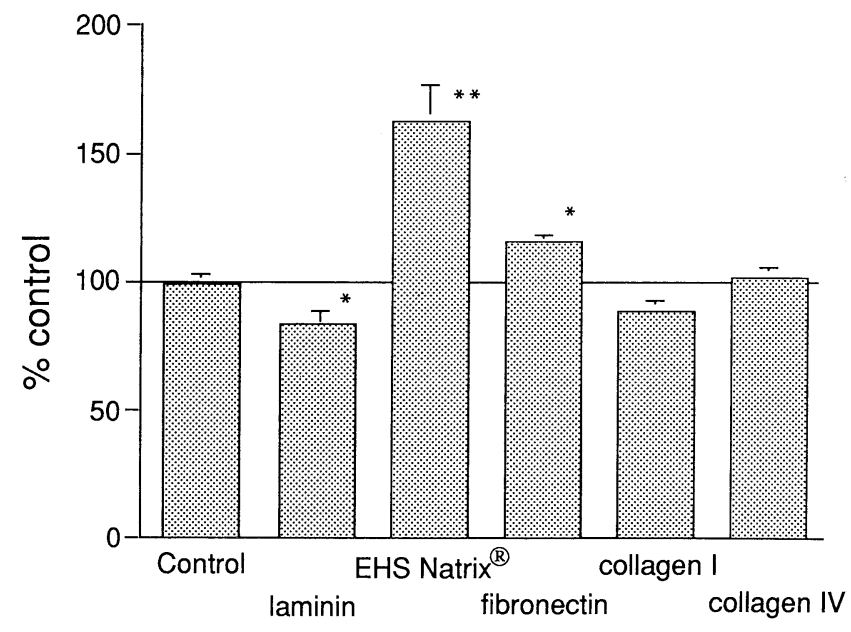

Fig. 8. The growth effects of ECMs to RPET cells. EHS-Natrix ${ }^{\circledR}$ had highest growth effects. Fibronectin also had some growth effects. Collagen types I and IV did not stimulate cell growth. A few inhibitory effects were shown by laminin. Bars indicate mean \pm SEM. ${ }^{*}: \mathrm{p}<0.01{ }^{* *}: \mathrm{p}<0.005$.

such as the requirement of $\mathrm{CM}$ from a culture of neuroretinal cells and decreased attachment to laminin. Because well-known growth factors did not stimulate RPET cell growth in the absence of CM, RPET cells may be useful for investigating a growth factor(s) from neuroretina.

Reportedly, EGF and bFGF have potent growth effects, whereas insulin and IGF-I have weak or modest growth effects on normal human RPE cells (22). EGF and bFGF had strong growth effects on RPET cells, and insulin and IGF-I and IGF-II had moderate growth effects. These growth effects, however, were observed only in the presence of CM. Even when combined, these five growth factors could not stimulate RPET cell growth if $\mathrm{CM}$ was not present. Our findings showed that $\mathrm{CM}$ was essential for the proliferation of RPET cells. In Balb/c 3T3 cells, IGF-II alone could not stimulate cell growth, but competent cells that were primed by EGF could be stimulated by IGF-II (15). Our results demonstrated that CM obtained from the culture of neuroretina include a factor(s) that may prime the growth of RPET cells, because the major growth factors stimulated RPE cell growth only in the presence of CM. Since it is not well understood whether growth factor from neuroretina stimulates RPE cells, RPET cells are good material for such an investigation.

RPE cells are epithelial cells. It is known that mam-

Fig. 9. Phase-contrast micrographs of RPET cells and tsSV40 neural retinal cells. (a) RPET cells on non-coated dish. (b) Two days' culture on laminin-coated dish. Cells were rounded and detached from dish bottom. (c) Cell culture continued on laminin-coated dish produced many colonies. (d) Transferred onto non-coated dish after 2 weeks' incubation on laminin-coated dish, cells immediately attached to dish bottom. (e) Temperature sensitive SV40 neuroretinal cells on laminin coated dish. Cells were attached, dispersed, and morphologically similar to those observed on the non-coated dish. (f) Normal cultured C57BL/6 mouse RPE cells on laminin-coated dish. The cells attached and spread on the laminin-coated dish. Bars indicate $50 \mu \mathrm{m}$. 

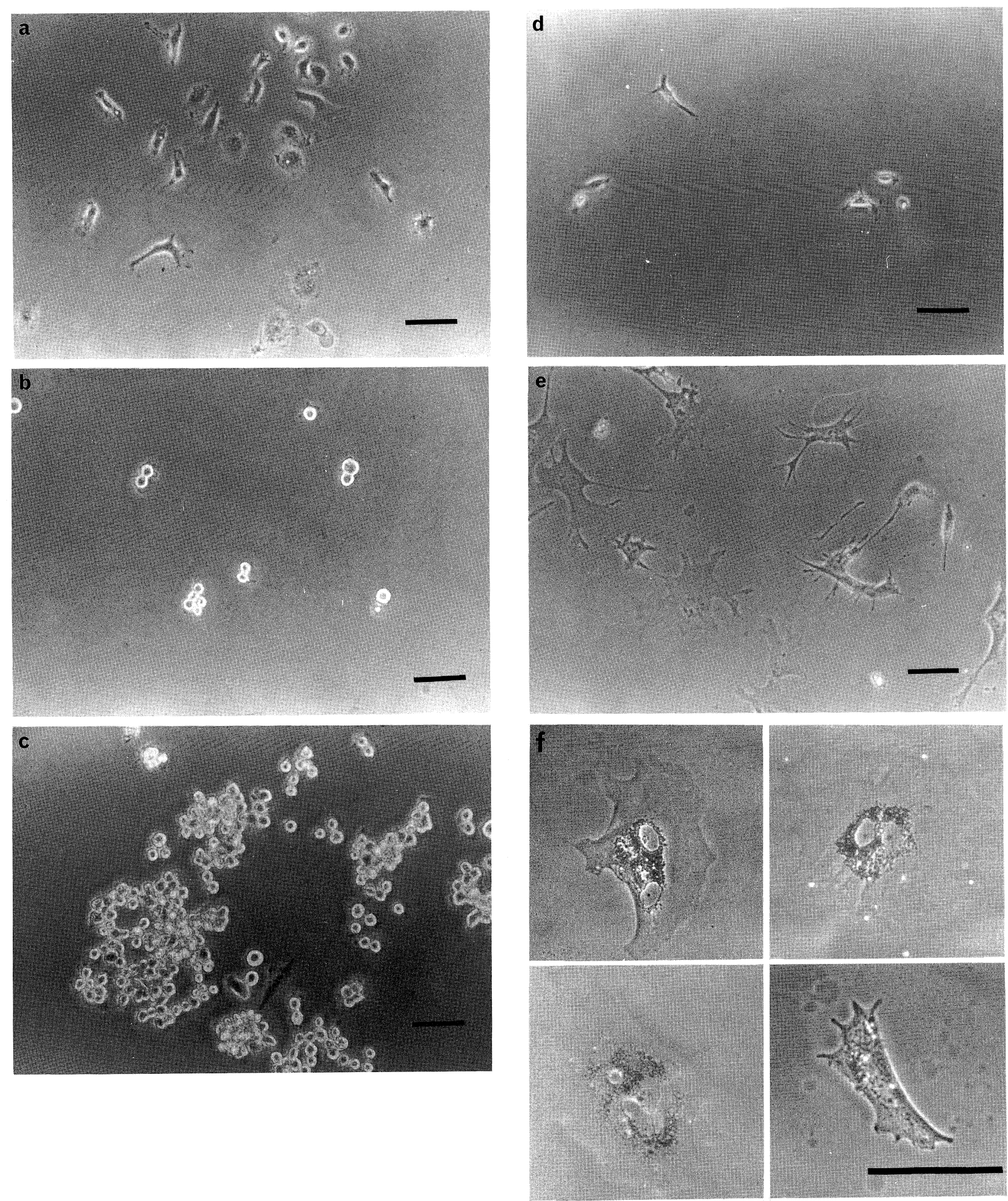

Fig. 9. 


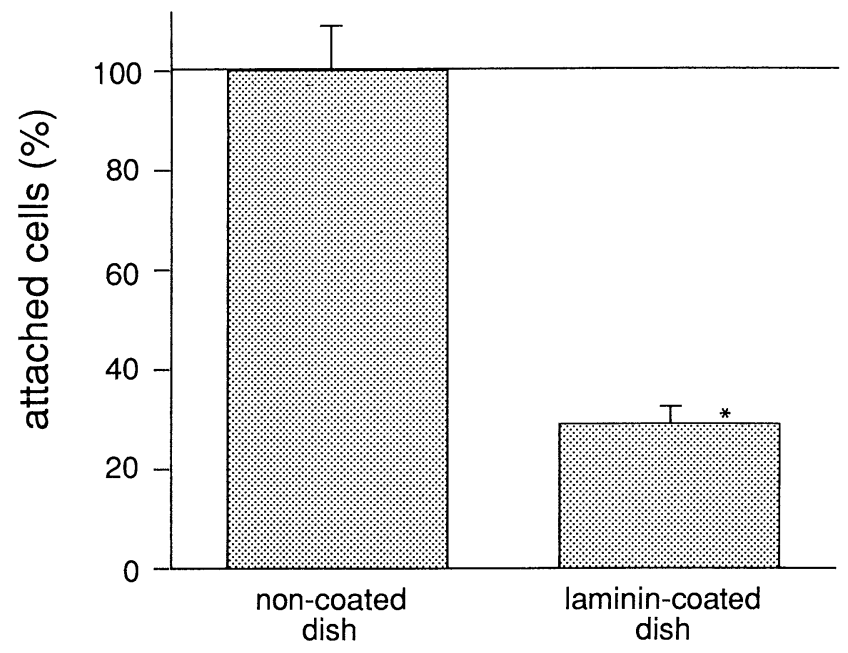

Fig. 10. The attachment to laminin on RPET cells. Only a few RPET cells were attached on the laminin-coated dish. Bars indicate mean \pm SEM. *: $\mathrm{p}<0.005$.

malian RPE cells have cytokeratin in vivo and in vitro. $(12,14,25,26,32,40-42)$. We confirmed that RPET cells also had cytokeratin. As seen by electron microscopy, RPET cells had the typical characteristics of RPE cells, such as microvilli on the cell surface and lysosome-like granules around the Golgi apparatus. RPET cells lost the typical morphological feature of RPE cells, which is its hexagonal cobblestone-like appearance. It is known that RPE cells can change into a mesenchymal phenotype (13). Although we observed no melanosomes which is characteristic of RPE cells, we detected the existence of T1-tyrosinase in the cytoplasm. These findings showed that the pathway of melanin formation in RPET cells was partially maintained.

ECM stimulates the proliferation of various types of cells. In normal RPE cells, fibronectin and polyD-lysine had growth effects, and collagen type I had no growth or inhibitory effects. In previous reports, Matrigel had inhibitory effects, and laminin had both growth and no growth effects $(7,13,44,50)$. In our experiments, EHS-Natrix ${ }^{\circledR}$, which is a component of Matrigel, and fibronectin had growth effects. The effects were relatively weak, as compared with growth factors. Laminin, fibronectin and collagens type I and IV had no growth or only a few inhibitory effects on RPET cells. Chick RPE cells did not spread and showed heavy pigmentation by Matrigel (31). No report has described the effects on the mouse RPE cells by Matrigel. On the other hand, previous reports described two different growth effects of laminin on RPE cells, stimulation and no effect $(13,44)$. In our examination, laminin had an inhibitory effect on RPET cells. The ability of laminin to promote the proliferation on various cell lines was mediated by a fragment of laminin and was not depend- ent on the adhesive properties of the molecule (33). It seemed to be a natural property that RPE cells do not grow on laminin, since RPE rests on Bruch's membrane, which contains laminin.

Laminin, a major component of Matrigel (18), has various biological functions (38), and it is the ECM obtained from Engelbreth-Holm-Swarm tumor. We could not observe this phenomenon in tsSV40 neuroretinal cells, and thus concluded that this property was not due to the tsSV40 large T-antigen gene. Also, this inability of RPET cells not to attach to laminin was not observed in normal mouse RPE cells. A macrophage cell line showed a weak attachment on laminin, and this cell line became round and adhered to the substratum less tightly (6). But to our knowledge, no report has described the morphological change of mouse RPE cells on laminin related to cell attachment. RPET cells had dramatic morphological changes on laminin, in spite of the fact that laminin is a major component of Bruch's membrane with collagen type IV (30). On the other hand, it has been reported that human RPE requires laminin to maintain its hexagonal shape (3). Because RPET cells could not attach to laminin, it might be that RPET cells could not form the hexagonal shape.

It is known that integrins are bound with ECMs and that laminin is also attached to integrins of cells. There are $8 \beta$ subunits and $12 \alpha$ subunits, and the ligand specificity is determined by a combination of both. Recently, several integrins have been shown to bind laminin. Depending on the cell type, these have included $\alpha 1 \beta 1$, $\alpha 2 \beta 1, \alpha 6 \beta 1, \alpha 7 \beta 1, \alpha \mathrm{v} \beta 3$, and possibly $\alpha 6 \beta 4(16,20,39)$. In addition, RPE cells have been reported to use the $\beta 1$ integrin subunit to adhere to laminin (5). The decreased adherence of Y79 retinoblastoma cells to other ECM proteins, as compared to normal human retinal cells can be attributed in part to their significantly lower levels of $\alpha 1, \alpha 2, \alpha 3$, and $\alpha 5$ integrin subunits, which serve as receptors for type IV collagen, laminin, and fibronectin (39). Kramer et al. reported that anti- $\alpha 6$ and anti- $\alpha \mathrm{v}$ antibody almost entirely blocked the attachment of human microvascular endothelial cells to laminin, but did not disturb the attachment to collagen type IV (20). The decreased attachment to laminin by RPET cells may also be due to the lack of some integrin on the cell surface. Many integrin subunits are not specific to ECMs and have something in common with all ECMs. Although there is a relatively specific subunit to laminin, it is difficult to explain why RPET cells could not attached to it. Because this clone (RPET cells) have a unique character which is different from normal RPE cells, RPET cells are a good model of the RPE chemotaxis mechanism on PVR.

In conclusion, we have established the tsSV40T retinal pigment epithelium derived-cell line (RPET cells) and have investigated its response to growth factors and 
ECM. RPET cells showed a dependency on novel neuroretina-derived growth factor(s). This growth effect of $\mathrm{CM}$ induced the primed competence of RPET cells and seemed to be caused by unknown factor(s). The combination of RPET cells and CM appears to be a good model for investigating the relationship between RPE cells and neuroretinal cells and also for studying the cell adhesion of RPE cells.

Acknowledgements. The authors thank Shigeru Sato $\mathrm{PhD}$ for his technical advice, and Maxine A. Gere for her help in English.

\section{REFERENCES}

1. Aronson, J.F. 1983. Human retinal pigment cell culture. In vitro., 19: 642-650.

2. Boyle, D.L. and MCLAughin, B.J. 1990. The effect of swainsonine on the phagocytosis of rod outer segments by rat RPE. Curr. Eye. Res., 9: 407-414.

3. Campochiaro, P.A. and Hackett, S.F. 1993. Corneal endothelial cell matrix promotes expression of differentiated features of retinal pigment epithelial cells: Implication of laminin and basic fibroblast growth factor as active components. Exp. Eye. Res., 57: 539-547.

4. Chaitin, M.H. and Hall, M.O. 1983. Defective ingestion of rod outer segments by cultured dystrophic rat pigment epithelial cells. Invest. Ophthalmol. Vis. Sci., 24: 812-820.

5. Chu, P. and Grunwald, G.B. 1991. Functional inhibition of retinal pigment epithelial cell-substrate adhesion with a monoclonal antibody against the $\beta 1$ subunit of integrin. Invest. Ophthalmol. Vis. Sci., 32: 1763-1769.

6. Das, A., Frank, R.N., Zhang, N.L., and Turczyn, T.J. 1990. Ultrastructural localization of extracellular matrix components in human retinal vessels and Bruch's membrane. Arch. Ophthalmol., 108: 421-429.

7. Docherty, R.J., Forrester, J.V., and LACKIE, J.M. 1987. Type I collagen permits invasive behavior by retinal pigmented epithelial cells in vitro. J. Cell Sci., 87: 399-409.

8. Dutt, K., Scott, M., Del Monte, M., Agarwal, N., Sternberg, P., Srivastava, S.K., and Srinivasan, A. 1990. Establishment of human retinal pigment epithelial cell lines by oncogene. Oncogene, 5: 195-200.

9. EDWARDS, R.B. and Szamier, R.B. 1977. Defective phagocytosis of isolated rod outer segments by RCS rat retinal pigment epithelium in culture. Science, 197: 1001-1003.

10. EDWARDS, R.B. 1991. Stimulation of rod outer segment phagocytosis by serum occurs only at the RPE apical surface. Exp. Eye. Res., 53: 229-232.

11. Frederiksen, K., Jat, P.S., Valtz, N., LeVy, D., and MCKay, R. 1988. Immortalization of precursor cells from the mammalian CNS. Neuron, 1: 439-448.

12. Fuchs, U., Kivelä, T., and TarkKanen, A. 1991. Cytoskeleton in normal and reactive human retinal pigment epithelial cells. Invest. Ophthalmol. Vis. Sci., 32: 3178-3186.

13. Grisanti, S. and GuIdRY, C. 1995 . Transdifferentiation of retinal pigment epithelial cells from epithelial to mesenchymal phenotype. Invest. Ophthalmol. Vis. Sci., 36: 391-405.

14. GuÉrin, C.J., ANDERson, D.H., and Fisher, S.K. 1990. Changes in intermediate filament immunolabeling occur in response to retinal detachment and reattachment in primates. Invest. Ophthalmol. Vis. Sci., 31: 1474-1482.
15. Heth, C.A., Yankauckas, M.A., Adamian, M., and EDWARDS, R.B. 1987. Characterization of retinal pigment epithelial cells cultured on microporous filters. Curr. Eye. Res., 6: 1007-1019.

16. Hynes, R.O. 1992. Integrins: Versatility, modulation, and signaling in cell adhesion. Cell, 69: 11-25.

17. JAT, P.S. and Sharp, P.A. 1989. Cell lines established by a temperature-sensitive simian virus 40 large-T-antigen gene are growth restricted at the nonpermissive temperature. Mol. Cell Biol., 9: 1672-1681.

18. Kleinman, H.K., McGarvey, M.L., Hassell, J.R., Star, V.L., Cannar, F.B., Laurie, G.W., and Martin, G.R. 1986. Basement membrane complexes with biological activity. Biochemistry, 25: 312-318.

19. Kleinman, H.K., Ogle, R.C., Cannon, F.B., Little, C.D., SWEENEY, T.M., and LUCKENBELL-EDDS, L. 1988. Laminin receptors for neurite formation. Proc. Natl. Acad. Sci. USA, 85: 1282-1286.

20. Kramer, R.H., Cheng, Y.F., and Clyman, R. 1990. Human microvascular endothelial cells use $\beta 1$ and $\beta 3$ integrin receptor complexes to attach to laminin. J. Cell Biol., 111: 1233-1243.

21. LA VEIL, M.M. 1976. Rod outer segment disk shedding in rat retina: Relationship to cyclic lighting. Science, 194: 1071-1074

22. Leschey, K.H., HACKeTt, S.F., Singer, J.H., and CAmpochiaro, P.A. 1990. Growth factor responsiveness of human retinal pigment epithelial cells. Invest. Ophthalmol. Vis. Sci., 31: 839-846.

23. Machemer, R. and Laqua, H. 1975. Pigment epithelium proliferation in retinal detachment (massive periretinal proliferation). Am. J. Ophthalmol., 80: 1-23.

24. Machemer, R., VAn Horn, D., and Aaberg, T.M. 1978. Pigment epithelial proliferation in human retinal detachment with massive periretinal proliferation. Am. J. Ophthalmol., 85: 181191.

25. Matsumoto, B., Guérin, C.J., and Anderson, D.H. 1990. Cytoskeletal redifferentiation of feline, monkey, and human RPE cells in culture. Invest. Ophthalmol. Vis. Sci., 31: 879889.

26. McKechnie, N.M., Boulton, M., Robey, H.L., Savage, F.J., and GrIERson, I. 1988. The cytoskeletal elements of human retinal pigment epithelium: in vitro and in vivo. J. Cell Sci., 91: 303-312.

27. Mclaren, M.J., Sasabe, T., Li, C.Y., Brown, M.E., and INANA, G. 1993. Spontaneously arising immortal cell line of rat retinal pigmented epithelial cells. Exp. Cell Res., 204: 311320 .

28. Moura Neto, V., Mallat, M., Chneiweiss, H., Prémont, J., Gros, F., and Prochiantz, A. 1986. Two simian virus 40 (SV40)-transformed cell lines from the mouse stratum and mesencephalon presenting astrocyte characters. I. Immunological and pharmacological properties. Dev. Brain. Res., 26: 1122.

29. Newsome, D.A., Rodrigues, M.M., and Machemer, R. 1981. Human massive periretinal proliferation: In vitro characteristics of cellular components. Arch. Ophthalmol., 99: 873880.

30. OHКI, K. and KoHASHI, O. 1994. Laminin promotes proliferation of bone marrow-derived macrophages and macrophage cell lines. Cell Struct. Funct., 19: 63-71.

31. Opas, M. 1989. Expression of the differentiated phenotype by epithelial cells in vitro is regulated by both biochemistry and mechanics of substratum. Dev. Biol., 131: 281-293.

32. OWAribe, K., Kartenbeck, J., RungGer-BrändLe, E., and 
FRANKE, W.W. 1988. Cytoskeletons of retinal pigment epithelial cells: Interspecies differences of expression patterns indicate independence of cell function from the specific complement of cytoskeletal proteins. Cell Tissue. Res., 254: 301-315.

33. Panayotou, G., End, P., Aumailley, M., Timpl, R., and ENGEL, J. 1989. Domains of laminin with growth-factor activity. Cell, 56: 93-101.

34. Paul, D., Höhne, M., Pinkert, C., Piasecki, A. UmmelmanN, E., and Brinster, R.L. 1988. Immortalized differentiated hepatocyte lines derived from transgenic mice harboring SV40 T-antigen genes. Exp. Cell Res., 175: 354-362.

35. Philp, N.J., Nachmias, V.T., Lee, D., Stramm, L., and BuZDYGoN, B. 1988. Is rhodopsin the ligand for receptor-mediated phagocytosis of rod outer segments by retinal pigment epithelium? Exp. Eye. Res., 46: 21-28.

36. Radna, R.L., Caton, Y., Jha, K.K., KaPlan, P., Li, G., Traganos, F., and Ozer, L. 1989. Growth of immortal simian virus 40 tsA-transformed human fibroblasts is temperature dependent. Mol. Cell Biol., 9: 3093-3096.

37. Seno, M., Sasada, R., Iwane, M., Sudo, K., Kurosawa, T., Ito, K., and IgaRAshi, K. 1988. Stabilizing basic fibroblast growth factor using protein engineering. Biochim. Biophys. Res. Commun., 151: 701-708.

38. Situ, R., Lee, E.C., McCoy, J.P., and Varani, J. 1984. Stimulation of murine tumour cell motility by laminin. J. Cell Sci., 70: $167-176$.

39. Skubitz, A.P.N., Grossman, M.D., McCarthy, J.B., WAYNER, E.A., and CAMERON, J.D. 1994. The decreased adhesion on Y79 retinoblastoma cells to extracellular matrix proteins is due to a deficit of integrin receptors. Invest. Ophthalmol. Vis. Sci., 35: 2820-2833.

40. Turksen, K., Opas, M., and Kalnins, V.I. 1989. Cytoskeleton, adhesion, and extracellular matrix of fetal human retinal pigment epithelial cells in culture. Ophthalmic. Res., 21: 56-66.

41. Vinores, S.A., Campochiaro, P.A., McGehee, R., Orman, W., HaCKetT, S.F., and HJelmeland, L.M. 1990. Ultrastructual and immunocytochemical changes in retinal pigment epithelium, retinal glia, and fibroblasts in vitreous culture. Invest. Ophthalmol. Vis. Sci., 31: 2529-2545.
42. Vinores, S.A., Herman, M.M., Hackett, S.F., and CAMpochiaro, P.A. 1993. A morphological and immunohistochemical study of human retinal pigment epithelial cells, retinal glia, and fibroblasts grown on Gelfoam matrix in an organ culture system. Grafe's Arch. Clin. Exp. Ophthalmol., 231: 279-288.

43. Williams, D.A., Rosenblatt, M.F., Beier, D.R., and Cone, R.D. 1988. Generation of murine stromal cell lines supporting hematopoietic stem cell proliferation by use of recombinant retrovirus vectors encoding simian virus 40 large T antigen. Mol. Cell Biol., 8: 3864-3871.

44. Williams, D.F. and BuRKe, J.M. 1990. Modulation of growth in retina-derived cells by extracellular matrices. Invest. Ophthalmol. Vis. Sci., 31: 1717-1723.

45. ҮАмамото, H. and TAKeUCH, T. 1981. Immunoelectron microscopic localization of tyrosinase in the mouse melanocyte. $J$. Histochem. Cytochem., 29: 953-958.

46. Yanai, N., Satoh, T., Kyo, S., Abe, K., Suzuki, M., and Obinata, M. 1991. A tubule cell line established from transgenic mice harboring temperature-sensitive simian virus 40 large Tantigen gene. Jpn. J. Cancer. Res., 82: 1344-1348.

47. Yanai, N., SuzuKi, M., and Obinata, M. 1991. Hepatocyte cell lines established from transgenic mice harboring temperature-sensitive simian virus 40 large T-antigen gene. Exp. Cell Res., 197: 50-56.

48. YounG, R.W. 1967. The renewal of photoreceptor cell outer segments. J. Cell Biol., 33: 61-72.

49. YounG, R.W. and BoK, D. 1969. Participation of the retinal pigment epithelium in the rod outer segment renewal process. $J$. Cell Biol., 42: 392-403.

50. Zhu, Z.R., Allameh, V., Sorgente, N., Ogden, T.E., and RYAN, S.J. 1989. Modulation of proliferation and chemotaxis of cultured RPE and endothelial cells by laminin. ARVO abstracts. Invest. Ophthalmol. Vis. Sci., 30 (Suppl): 203.

(Received for publication, August 21, 1996 and in revised form, October 7, 1996) 